\section{Oleksandr Bezruchko}

Doctor in Art Studies,

Professor of the Department of Cinema and Television Art of the Kyiv National University of Culture and Arts

\section{Олександр Безручко}

доктор мистецтвознавства, професор кафедри кіно-телемистецтва Київського національного університету культури і мистецтв

\title{
The Beginning of the Artistic and Mentoring Activities OF O. DOVZHENKO
}

\author{
ПОЧАТОК МИСТЕЦЬКО-НАСТАВНИЦЬКОЇ ДІЯЛЬНОСТІ О. П. ДОВЖЕНКА
}

\begin{abstract}
Summary. The beginning of the artistic and mentoring activity of the genius Ukrainian film director and script writer Oleksandr Dovzhenko was investigated and analyzed at the article; his cinema-pedagogical activity at the Odessa State College of Cinematography of the All-Ukrainian Photo Cinema Management was studied; the possibilities of attraction to teaching at the Theatre Cinema Photo Department of the Kyiv Art Institute were clarified. We established the facts of Oleksandr Dovzhenko's work in the methodological commissions on "Film Director's work" and "Sociology and History of Arts, History of Material Culture, History of Cinema” at the Artistic Faculty of the Kyiv State Institute of Cinematography.

Keywords: history of cinema, Oleksandr Dovzhenko, Odessa State College of Cinematography, film director, Kyiv Art Institute, methodological commission.
\end{abstract}

Problem statement. The urgency of this study is caused with the lack of special studies on cinema-pedagogical activity of O. Dovzhenko in Ukraine, with the need to create a complete and objective biography of the artist and trace his influence on the formation and development of Ukrainian cinema education in the 1930s and 1940s, to clarify the biography of O. Dovzhenko, discovering and publishing an unknown layer of sources from formerly closed state and personal archives, special storages, and libraries.

Analysis of recent research works and publications. The beginning of the cinema-pedagogical activity of O. Dovzhenko at the Odessa State College of Cinematography of the All-Ukrainian Photo Cinema Management was investigated by $\mathrm{O}$. Shimon [17], but the chronological framework of his work did not allow to clarify the further Dovzhenko's cinema-pedagogical experiments. Some aspects of the cinema-pedagogical activity of O. Dovzhenko were considered in the works of G. Zhurov [8], M. Shudra [18], L. Cherevatenko [16] and O. Bezruchko [1;2].

Objectives of the study are to research the start of the artistic and mentoring activity of Ukrainian feature films director O. Dovzhenko; to analyze his cinemapedagogical activity at the Odessa State Institute of Cinematography of the All-Ukrainian Photo Cinema Management; to find out the possibility of engaging in teaching at the Theatre Cinema Photo Department of the Kyiv Art Institute; to discover the facts of Oleksandr Dovzhenko's work in the methodological commissions "Film Director's work" and "Sociology and History of Arts, History of Material Culture, History of Cinema” at the Artistic Faculty of the Kyiv State Institute of Cinematography.

The aim of the article was to study and analyze the beginning of cinema-pedagogical activity of the genius
Ukrainian film director O. Dovzhenko at the Odessa State College of Cinematography of the All-Ukrainian Photo Cinema Management, the Theatre- Cinema- Photo- Department of the Kyiv Art Institute and at the Artistic Faculty of the Kyiv State Institute of Cinematography.

Presentation of the main research material. Cinema-pedagogical activity of O. Dovzhenko began at the Odessa State College of Cinematography of the AllUkrainian Photo Cinema Management (1924-1930), whose students during the internship at the Odessa Film Factory "definitely felt into the crew of Dovzhenko... Former student Georgy Zhurov recalled that those who managed to become the assistants of Oleksandr Dovzhenko were considered lucky" [12, p. 258]. It is known for certain that one of the students in the Dovzhenko film Vasya-Reformator was Yuri Tamarsky [16, p. 53].

According O. Shimon, a cinema historian, good results in the cinema-pedagogical practice of the Odessa State College of Cinematography gave such a form of training as seminars on the profile, which included lectures and reports on specific problems of cinema and related arts, practical tasks, followed by collective analysis, review and discussion of the new films, interesting printed works, creative trips to the Moscow and Leningrad film factories. Kuleshov, Eisenstein, Pudovkin, and Dovzhenko were invited as a lecturers for these seminars [17, p. 133]. Yet, according to Oleksandr Shimon, only the latter two managed to actually make it.

Although O. Dovzhenko did not have the studio of his own, he did not bypass the Odessa State College of Cinematography of Cinematography of the All-Ukrainian Photo Cinema Management. The memoirs of G. Zhurov confirm this: "For the qualifying (diploma) works O. Denisov invited the well-known figures of the theater 
and screen art-A. Buchma, O. Dovzhenko, G. Roshal, G. Taskin, I. Kavaleridze” [8, p. 4].

For the coordination of the theoretical developments of qualification works of the students with practical questions and further correction of the revealed shortcomings, the management of the Odessa State College of Cinematography introduced a system of preliminary protection. "Only during the academic year of 1927-1928 the qualification commission conducted 22 preliminary thesis defenses, invited by the workers of the film factory (apparently, including O. Dovzhenko)” [12, p. 259].

The Odessa State College of Cinematography widely used such a form of training as an assistant-internship, which then played a leading role in the cinema-pedagogical method of O. Dovzhenko.

A lot of attention had been paid to a group of twelve film directors and cameramen, specializing in children's films. For them, the People's Commissariat of Ukraine organized a seminar on pedagogy, with O. Dovzhenko and O. Korniychuk participating, which included lectures on the following topics: "Methods of directing the children's film”, "Specificity of the children's film", "Cinema and its means of artistic influence”, "Scenario for children” [17, p. 133].

A progressive creative youth was always around O. Dovzhenko. As noted in the documents, recently declassified by the Security Service of Ukraine, "Dovzhenko, working at the Odessa Film Factory... has grouped a nationalistic youth around him" [7, p. 296].

In contrast to Theatre Cinema Photo Department of the Kyiv Art Institute-KAI (which existed during 1926-1930), where, prior to the establishment of the Kyiv Film Factory, the main emphasis in the teaching of students was on the theory of art, the Odessa State College of Cinematography focused mainly of practical studies, and therefore many students of cinema technology, such as M. Kulchytskyi, were "lucky to take part in the filming of O. Dovzhenko's films Zvenigora and Arsenal" [3, p. 13].

However, the Director of the Odessa State College of Cinematography of the All-Ukrainian Photo Cinema Management $M$. Kharitonov believed that the emphasis on the practical work had its negative consequences, "The students of the Odessa State College of Cinematography were more or less skilled from the technical point of view, but of extremely poor general political and ideological culture; it was equally bad with their artistic culture as well. It was our tragedy. Here, in Kyiv [at the Theatre Cinema Photo Department of the Kyiv Art Institute], everything provided a high artistic culture, but the other side of the matter - technical training-was drastically poor» [13, p. 286]. After organizing the Kyiv State Institute of Cinematography M. Kharitonov became his first director and tried not to repeat the mistakes of the College of Cinematography in the newly created Institute of Cinematography.

The Kyiv Art Institute, led by I. Vrona, tried to correct this situation, and following the opening of the Kyiv Film Factory in 1928 invited its leading specialists to the Theatre Cinema Photo Department. "Dovzhenko received the proposal to teach. However, the attempts to find documents certifying his teaching activity at the Theatre Cinema Photo Department has little success yet” [12, p. 259].

In the Odessa State College of Cinematography "a team of professionals assembled, very strong for its time, who were experts in the field of history of culture and art. In different times such outstanding cinema practitioners as A. Buchma, I. Kavaleridze, G. Roshal, O. Dovzhenko were trying to transfer their great creative experience and knowledge to the students” [17, p. 129-130].

Still, the Kyiv State Institute of Cinematography (KSIC), which had a significantly higher level of education, played a major role in the formation of Ukrainian cinema education of the pre-war period.

It should be noted that O. Dovzhenko paid a lot of attention to attracting Ukrainian youth to the cinema production. Thus, in the end of 1929, he called for the reception of the film-makers by the secretariat of the Central Committee of the Leninskyi Komsomol, "The motto of today is the newest staff of film workers from the working masses, from the youth, from the Komsomol” [9].

After returning to Ukraine O. Dovzhenko actively engaged in the development of the curricula for students of the Art Department of the Kyiv State Institute of Cinematography, "On November 16, 1930 a methodical commission meeting took place. Oleksandr Dovzhenko and Mykola Shpikovskyi were instructed to develop a directing program for all departments of the Artistic Faculty during the ten days: film director's department, cameraman's department and script writer's department” [14, p. 703].

At the meeting, Dovzhenko and Shpikovskyi's proposal for organizing methodological lectures on art, in particular, workshops by Sergei Eisenstein and Dzyga Vertov, was approved.

So, immediately after arriving from a foreign business trip, the artist entered the cinema-pedagogical work of the Kyiv State Institute of Cinematography.

In he early December of 1930 O. Dovzhenko worked not only in the methodological commission on "Film Director's work" [14, p. 693] (chairmen of the commission were I. Bokhonov, Dzyga Vertov, D. Marian, M. Shpykovskyi and A. Vinnitskyi), but also in the methodological commission on the faculty of "Sociology and History of Arts, History of Material Culture, History of Cinema" (commission chairmen were I. Vrona, S. Gilyarov, Y. Savchenko) [14, p. 693].

Oleksandr Dovzhenko planned to use the Artistic Faculty of the Kyiv State Institute of Cinematography in the future as, could be understood from the following document: "The teaching staff has been invited to participate in the work of methodical commissions of film directors, scriptwriters and editors of the film factorypeople who, although not connected with direct teaching at the Institute, were undoubted future leaders of the production training of students at a film factory... Dovzhenko” [14, p. 696].

First, at the Kyiv Film Factory, and then at the Kyiv State Institute of Cinematography, one-year courses of the scriptwriters were organized, which "can be used as pedagogical forces... of Dovzhenko” [14, p. 299].

"During all the years of our stay at the institute", T. Levchuk believed, "the spirit of Dovzhenko reigned over us all the time. A large group of our course, as a rule, was trained in the film crews of Ivan and Shchors" [10, p. 61-62].

In the early 1930s, Oleksandr Dovzhenko was opposed to prolonging the course for film directors for several years, "One year is enough to teach the cinema art. What is more important is to feel the need for a film. 
As soon as it comes-you need to immediately immerse yourself in your head” [11, p. 71]. It was his personal way of shooting films and training his students: he paid a lot of attention to immersion in the cinematic process or internship.

Dovzhenko saw the main way of teaching students in engaging them into the practical work on the film. An important aspect in the pedagogical process for Oleksandr Dovzhenko was the moment of conception, and considering that introspection, walks, conversations, discussions were widely used, during which all the components of the cinematic process were discussed informally.

The Kyiv State Institute of Cinematography actively discussed the issue of the specialization (or as it was then called "ukhyliv") of the film directors; it introduced the active teaching methods with "the lecture as a way of learning remains minimal within the programme. The lectures are replaced, in addition to purely industrial training at the enterprises, with the seminars, laboratory works, brigades, etc.” [14, p. 697]; the administration of the Institute tried to attract the best specialists working in the Ukrainian cinema [14, p. 286].

O. Dovzhenko as a productive, creative person, a member of the methodological commission of the Artistic Faculty of Kyiv State Institute of Cinematography, actively engaged in discussing, developing and implementing the Institute's many new pedagogical methods, including the problem of specialization in filmdirecting [14, p. 697]. Confirmation of this is the performance of the artist at the First All-Ukrainian Congress of the Friendship Society of Soviet Photography and Cinematography in April 1931, in which he thoroughly analyzed the process of cinematography differentiation, the errors of young filmmakers whose first films became "cultural films": "The production of a cultural film is often entrusted to a young beginner director, who, looking at this work as something minor, wasting thousands of meters of film, believes that he must do various risky experiments, until he is entrusted with artistic production movie" [4].

After revealing the problem ("due to such careless attitude to work on a cultural film, the latter gets on the wide screen and does not succeed" [5]) O. Dovzhenko always showed the ways of its solution: "Cultural film must have a minimum footage at maximum shooting points. He must show the facts as clearly as possible, their purposefulness" [4].

Dovzhenko did not ignore the problems of introducing the "sound cinema" and the development of a children's film in Ukraine: "We gathered in Kyiv with teachers and they were interviewed, saying that we are really starting to step on the higher pedagogical front" [15, p. 7].

But the main thing for O. Dovzhenko was not the sphere of film directing in which the student will work. He considered very important a film director to be a personality and a talented person. Probably due to this principle of pedagogical method a lot of his students became true artists, who established themselves not only in the cinema, but also in poetry, acting, etc.

In 1939, in one of the jubilee editions of the Art of Cinema, it was noted that there are film directors, and quite remarkable film directors, such as the Vasiliev brothers, who really dissolve in their films. Also there are film directors, such as S. Eisenstein and O. Dovzhenko, each frame of whose films could only be from their films. If film directors of the same type were given the same script, each one would have shot an entirely different movie. Oleksandr Dovzhenko stated on this regard, "Would the screening of one and the same script with the same performers of roles, but by five different directors result in five different films?” [6, p. 192]. Giving the film director all the rights (the right of the main organizer and the author of the film), the master believed that "it is necessary to require a detailed classification of the material from him, which will determine the essence and the fact of the finished film” [6, p. 192]. According to Dovzhenko, this material is primarily a script that "coincides with the personal preferences of the director, and this pushes him into screen adaptation-it does not matter if he wrote this script himself or has received it half-finished. Only in this case one can speak about the $100 \%$ interest of the author of the film in the full success of the work" [6, p. 192]. It is very important for a film director, and Dovzhenko emphasized that at all times of his cinema-pedagogical activity, to find his theme: "The film director who is engaged in the screening of a random topic, is a slave of someone else's idea. The film director, who himself raised the idea, is a master who creates a true artistic value” [6, p. 192].

Therefore, the main thing, according to O. Dovzhenko, was to educate young filmmakers, not artisans, "The activity of a filmmaker should rise and go far from the sphere of commercial interests and the blind execution of orders in the sphere of realization of their own world outlook with the help of cinematographic means" [6, p. 192].

According to Oleksandr Dovzhenko's firm standpoint, except for the talent, without which it is impossible to exist in art, the students must study persistently and continuously.

Conclusions. We set a goal to investigate and analyze the beginning of the artistic and mentoring activity of the genius Ukrainian film director and script writer Oleksandr P. Dovzhenko. The goal was achieved.

Summerizing the abovementioned, it can be noted that the scientific tasks have been fulfilled: the artistic and mentoring activity of the Ukrainian director was investigated; his cinema-pedagogical activity at the Odessa State College of Cinematography of the All-Ukrainian Photo Cinema Management was analyzed; the possible reasons, why Dovzhenko was attracted to teaching at the Theatre Cinema Photo Department of the Kyiv Art Institute were clarified. We established the facts of Oleksandr Dovzhenko's work in the methodological commissions on "Film Director's work" and "Sociology and History of Arts, History of Material Culture, History of Cinema" at the Artistic Faculty of the Kyiv State Institute of Cinematography.

Prospects for the further research. Despite the thorough scientific study of the beginning of cinema-pedagogical activity, we believe that the perspectives of scientific research remain significant, since the teaching activity of Oleksandr Dovzhenko in the second half of the 1920s remains completely unstudied. 


\section{Literature}

1. Безручко О. В. Педагогічний метод О. П. Довженка: навчальний посібник; Київ. міжнар. ун-т. [вид. 2-ге, доп.]. Київ: КиМУ, 2012. Т. 1. 266 с.

2. Безручко О. В. Педагогічний метод О. П. Довженка: навчальний посібник; Київ. міжнар. ун-т. [вид. 2-ге, доп.]. Київ: КиМУ, 2012. Т. 2. 238 с.

3. Данько Т. Майстер // Новини кіноекрана. 1984. № 11. С. 13.

4. Довженко О. 3 дебатів по доповіді т. Воробйова на Першому всеукраїнському з”ізді ТДРФК // Кіногазета. 1931. № 10.

5. Довженко О. Мовою доступною мільйонам // За більшовицький фільм. 1937. 27 лютого.

6. Довженко О. П. Твори: у 5 т. / упоряд. Ю. І. Солнцева, Т. П. Дерев’янко. Київ: Дніпро, 1984. Т. 4: Статті, виступи, лекції. 352 с.

7. Довідка начальника 2-го відділу УдБ НКВС УРСР Ткаченка про О. Довженка // Галузевий державний архів Служби безпеки України (ГДА СБ України). Ф. 11. Спр. С-836. Т. 1. Арк. 296.

8. Журов Г. Як вони починали // Новини кіноекрана. 1989. № 6. С. 4.

9. Комсомолець України. 1929. 15 грудня.

10. Левчук Т. В. Тому що люблю: спогади кінорежисера. Київ: Мистецтво, 1987. 200 с.

11. Лейда Д. Коммунист. Поэт. Философ // Искусство кино. 1984. № 10. С. 69-72.

12. Росляк Р. Незатребуваний потенціал // Довженко і кіно ХХ століття: зб. ст. Київ: Вид. поліграф центр «ТАТ», 2004. С. 257-262.

13. Центральний державний архів вищих органів влади та управління України (ЦдАВО України). Ф. 1238. Оп. 1. Спр. 193.

14. ЦДАВО України. Ф. 1238. Оп. 1. Спр. 196.

15. Центральний державний архів-музей літератури і мистецтва України (ЦдАМЛМ України). Ф. 690. Оп. 4. Спр. 74.

16. Череватенко Л. Хто ж такий Тамарський? // КІNO-КОЛО. 2001. Осінь (11). С. 49 Н́63.

17. Шимон А. А. Начало кинообразования // Страницы биографии украинского кино. Киев: Мыстэцтво, 1974. С. 123-140.

18. Шудря М. Геній найщирішої проби: нариси, розвідки, рецензії, інтерв’ю, публікації. Київ: Юніверс, 2005. 382 с.

\section{References}

1. Bezruchko O.V. Pedahohichnyi metod O. P. Dovzhenka: navchalnyi posibnyk [Bezrudko O. V. Pedagogical method O. P. Dovzhenko: textbook]; Kyiv. mizhnar. un-t. [vyd. 2-he, dop.]. Kyyiv: KyMU, 2012. T. 1. 266 s.

2. Bezruchko O.V. Pedahohichnyi metod O. P. Dovzhenka: navchalnyi posibnyk [Bezrudko O. V. Pedagogical method O. P. Dovzhenko: textbook]; Kyiv. mizhnar. un-t. [vyd. 2-he, dop.]. Kyyiv: KyMU, 2012. T. 2. 238 s.

3. Danko T. Maister [Danko T. Master] // Novyny kinoekrana [News of the cinema]. 1984. № 11. S. 13.

4. Dovzhenko O. Z debativ po dopovidi t. Vorobiova na Pershomu vseukrainskomu zizdi TDRFK [Dovzhenko O. From the debates on the report, Mr. Vorobiev at the First All-Ukrainian Congress of the Society of Friends of Soviet Cinematography and Photography] // Kinohazeta. 1931. № 10.

5. Dovzhenko O. Movoiu dostupnoiu milionam [Dovzhenko O. In the language available to millions] // Za bilshovytskyi film [// For the Bolshevik film]. 1937. 27 liutoho.

6. Dovzhenko O. P. Tvori: u 5 t. [Dovzhenko O. P. Works: In 5 volums] / uporyad. Yu. I. Solntseva, T. P. Derev’yanko. Kyiv: Dnipro, 1984. T. 4: Statti, vistupi, lektsiyi [Vol. 4: Articles, Speeches, Lectures]. 352 s.

7. Dovidka nachalnyka 2-ho viddilu UDB NKVS URSR Tkachenka pro O. Dovzhenka [Reference of the head of the 2 nd Department of the UDC of the NKVD of the UkrSSR Tkachenko about O. Dovzhenko] // Haluzevyi derzhavnyi arkhiv Sluzhby bezpeky Ukrainy [Sectoral State Archive of the Security Service of Ukraine] (HDA SB Ukrainy). F. 11. Spr. S-836. T. 1. Ark. 296.

8. Zhurov H. Yak vony pochynaly [Zhurov G. How they started] // Novyny kinoekrana [News of the cinema]. 1989. № 6. S. 4.

9. Komsomolets Ukrainy [Komsomolets of Ukraine]. 1929. 15 hrudnia.

10. Levchuk T. V. Tomu shcho liubliu: spohady kinorezhysera [Levchuk T. V Because I love: the memories of the film director]. Kyyiv: Mystetstvo, 1987. $200 \mathrm{s.}$

11. Leyda D. Kommunist. Poet. Filosof [Leida J. The Communist. Poet. Philosopher] // Yskusstvo kyno [Art of Cinema.]. 1984. № 10. S. 69-72.

12. Rosliak R. Nezatrebuvanyi potentsial [Roslyak R. Untapped potential] // Dovzhenko i kino XX stolittia: zb. st.[ Dovzhenko and cinema of the twentieth century: collection of articles]. Kyiv: Vyd. polihraf. tsentr «TAT», 2004. S. 257-262.

13. Tsentralnyi derzhavnyi arkhiv vyshchykh orhaniv vlady ta upravlinnia Ukrainy [Central State Archive of the Supreme Governments and Administrations of Ukraine] (TsDAVO Ukrainy). F. 1238. Op. 1. Spr. 193.

14. Tsentralnyi derzhavnyi arkhiv vyshchykh orhaniv vlady ta upravlinnia Ukrainy [Central State Archive of the Supreme Governments and Administrations of Ukraine] (TsDAVO Ukrainy). F. 1238. Op. 1. Spr. 196.

15. Tsentralnyi derzhavnyi arkhiv-muzei literatury i mystetstva Ukrainy [Central State Archive-Museum of Literature and Art of Ukraine] (TsDAMLM Ukrainy). F. 690. Op. 4. Spr. 74.

16. Cherevatenko L. Khto zh takyi Tamarskyi? [Cherevatenko L. Who is Tamarsky?]// KINO-KOLO. 2001. Osin (11). S. 49-63.

17. Shymon A. A. Nachalo kynoobrazovanyia [Shimon A. A. The beginning of film education] // Stranytsy by- 
ohrafyy ukraynskoho kyno [Pages of the biography of the Ukrainian cinema]. Kyyiv: Mystetstvo, 1974. S. 123140.

18. Shudria M. Henii naishchyrishoi proby: narysy, rozvidky, retsenzii, interviu, publikatsii [Shudry M. Genius of the sincere test: essays, intelligence, reviews, interviews, publications]. Kyyiv: Yunivers, 2005. $382 \mathrm{~s}$.

\section{Олександр Безручко}

Початок мистецько-наставницької діяльності О. П. Довженка

У статті досліджено початок мистецько-наставницької діяльності геніального українського кінорежисера та сценариста Олександра Петровича Довженка; проаналізовано його кінопедагогічну діяльність в Одеському державному технікумі кінематографії Всеукраїнського фотокіноуправління; з'ясовані можливості залучення до викладання на теакінофотовідділі Київського художнього інституту; встановлені факти роботи Олександра Довженка в методологічних комісіях «Режисерська справа» та «Соціологія та історія мистецтв, історія матеріальної культури, історія кіномистецтва» на художньому факультеті Київського державного інституту кінематографії.

Ключові слова: історія кіно, Довженко Олександр Петрович, Одеський державний технікум кінематографії, кінорежисер, Київський художній інститут, методологічна комісія.

\section{Александр Безручко \\ Начало художественно-наставнической деятельности А. П. Довженко}

В статье исследуется начало художественно-наставнической деятельности гениального украинского кинорежиссера и сценариста Александра Петровича Довженко; проанализирована его кинопедагогическая деятельность в Одесском государственном техникуме кинематографии Всеукраинского фото- и киноуправления; установлена возможность его привлечения для преподавания в теакинофотоотделе Киевского художественного института; установлены факты работы Александра Довженко в методологических комиссиях «Режиссерское дело» и «Социология и история искусств, история материальной культуры, история кино» на художественном факультете Киевского государственного института кинематографии.

Ключевые слова: история кино, Довженко Александр Петрович, Одесский государственный техникум кинематографии, кинорежиссер, Киевский художественный институт, методологическая комиссия. 